Article

\title{
Characterization of the Water Quality Status on a Stretch of River Lérez around a Small Hydroelectric Power Station
}

\section{Enrique Valero}

Research Group AF4, Department of Natural Resources and Environment Engineering, School of Forestry Engineering, University of Vigo, Campus A Xunqueira s/n., Pontevedra 36005, Spain; E-Mail: evalero@uvigo.es; Tel.: +34-986-801-903; Fax: +34-986-801-907

Received: 16 August 2012; in revised form: 13 September 2012 / Accepted: 13 September 2012 / Published: 15 October 2012

\begin{abstract}
The renewable energy emerged as a solution to the environmental problems caused by the conventional sources of energy. Small hydropower (SHP) is claimed to cause negligible effects on the ecosystem, although some environmental values are threatened and maintenance of an adequate water quality should be ensured. This work provides a characterization of the water quality status in a river stretch around a SHP plant on river Lérez, northwest Spain, for four years after its construction. The ecological and chemical status of the water as well as the ecological quality of the riparian habitat, were used as measures of quality. Data were compared with the water quality requirements. The variations in the quality parameters were analyzed over time and over the river sections with respect to the SHP plant elements. Two years after construction, the temperature and dissolved oxygen values achieved conditions for salmonid water and close to the reference condition, while $\mathrm{pH}$ values were low. The Iberian Biological Monitoring Working Party (IBMWP) index showed a positive trend from two years after the construction and stabilized at "unpolluted or not considerably altered water". Quality parameters did not present significant differences between sampling points. The SHP plant construction momentarily altered the quality characteristics of the water.
\end{abstract}

Keywords: biological index; IBMWP; riparian forest quality index (QBR); macrobenthos; physicochemical; SHP plant 


\section{Introduction}

Human society needs energy for industry, transportation, household heat and electricity; in developed countries our lifestyle is totally dependent on electricity. Electricity accounted for $21 \%$ of the energy consumption of European Union (EU) in 2007: 27.4\% for the industrial sector and 39.5\% for service and households [1]; its demand has increased at an average rate of $2 \%$ annually since 1990 and the prediction is that this growth will continue in the future [1].

Electrical generation by conventional sources of energy, i.e., thermal electricity generated by fossil fuels (coal, petroleum, or gas) burning, remain the main source of electricity generation with a contribution of $54.5 \%$ to the total electricity production in the EU27 in 2010 [2]. However, the conventional energy system model has problems linked to the depletion of the world's non-renewable energy sources [3], the problematic dependence on fossil fuels and the emergence of environmental problems [4]. Main environmental issues related with electric energy production from fossil fuel combustion are: (a) acid rain; (b) ozone depletion caused by $\mathrm{NO}_{\mathrm{x}}$ emissions; and (c) the greenhouse effect or global warming [3,5].

Renewable energy technologies emerged as the most important solution to these environmental problems $[3,4]$. Promotion of renewable energy is a key strategy for reducing greenhouse gas emissions, and thus contributes to the achievement of the climate change mitigation goals of the Kyoto Protocol. Due to their environmental benefits, and in order to diversify the energy supply, its development has been one of the central objectives of community energy policy [4]. Renewable energy technologies convert renewable sources to useful forms of energy such as heat, electricity, mechanical power or fuels. Among them, green power is the electricity generated from wind, solar, small hydro, geothermal and biomass sources [6].

Hydropower is the most traditional clean renewable energy source and the most important for electrical power production worldwide; specifically it provides about $17 \%$ of EU electricity supply [7]. The energy source of hydropower is running water from rivers or streams. In run-of-river small hydro power (SHP) schemes, part of the flow of the stream is diverted through a pipe which takes the water to a penstock where it is forced to fall into hydro-turbines situated in the powerhouse. These turbines convert water pressure into mechanical shaft power, which can be used to drive an electricity generator. Afterwards the flow comes back to the stream [7]. Usually, the fall is enhanced and the diversion facilitated by constructing a small dam which increases the head (elevation difference between the water's surface and the turbine), although these dams are quite small and generally little or no water is stored [7]. SHP is one of the most cost-effective renewable energy technology with a high capacity utilization factor [6]. SHP has many other advantages as an extremely robust technology, since systems can last for 50 years or more with little maintenance, and it is claimed to be one of the most environmentally benign energy technologies available [7].

There is still no internationally agreed definition of SHP. A maximum of $10 \mathrm{MW}$ is the most widely accepted value worldwide although the definition in China stands officially at $25 \mathrm{MW}$ [7]. In Europe, SHP is defined as below 10 MW [8]. In 2002, Galicia (region in the northwest Spain) had 81 small hydro stations with a total installed capacity of $169 \mathrm{MW}$, which represented $7.5 \%$ of installed small hydro capacity in Spain [4]. The region of Galicia is suitable for hydraulic power schemes and specially for SHP due to its climatic and topographic characteristics: an average annual precipitation of $1180 \mathrm{~mm}$ [9], a 
granitic geological composition and a relief which produce a wide river network [10], combined with an abrupt topography.

Despite the environmental benefits of the SHP, some ecological values are still threatened by this form of renewable energy. SHP plants are located in such important stream ecosystems, generally in areas of high ecological value. Main harmful effects are related with: stream ecosystem fragmentation and fish passage [11,12], alteration of the natural hydrologic regime [13] and of the water quality with respect to physicochemical conditions and benthic communities affected [13-16], and lack of SHP equipment and constructions integration in the landscape [8].

Rivers need adequate water quality to sustain ecological processes and species associated, as well as to ensure providing associated goods and services. Uses established in rivers should not jeopardize the remaining functions and uses of these ecosystems. In this way, SHP plants should be compatible with the maintenance of an adequate water quality in affected reaches.

The requirements about water quality in European rivers is determined by the Water Framework Directive of the European Union (WFD; Directive 2000/60/EC [17]), from now WFD. The purpose of the WFD is to establish a framework for the protection of inland surface waters (between others). This directive aims to prevent further deterioration, protect and enhance the status of aquatic ecosystems, at the same time that promotes sustainable water use based on a long-term protection of these resources. Surface water status is defined in the article 2 of [17] as the general expression of the status of a body of surface water, determined by the poorer of its ecological status and its chemical status. In order to describe the status of the waters, WFD includes consideration of: (1) biological elements such aquatic flora, benthic invertebrates and fish; (2) hydromorphological elements such as water flow, groundwater dynamics, river depth, width and continuity; and (3) chemical and physiochemical elements such as thermal and oxygenation conditions, salinity, acidification, nutrients, and specific pollutants [18]. To achieve of WFD goals, the EU has established the "Blueprint to Safeguard Europe's Water", aimed to outline a strategy that will ensure good quality water in sufficient quantities for all legitimate uses by 2020. This more holistic view, that incorporates ecosystem services, is contemplated in the freshwater ecosystem "vulnerability" concept.

The aim of this research is to describe the quality of the riverine ecosystem on a river stretch which includes a SHP plant on river Lérez, Galicia (northwest Spain). The ecological and physicochemical status of the stream water as well as the ecological quality of the riparian vegetation, were used as measures of quality. For this aim, the variations existing in the quality parameters were analyzed according to the location of the sampling points with respect to the plant elements, and through the time from the plant installation. Data were compared with the closest station belonging to the Aguas de Galicia Water Quality Control Network, with the Reference Conditions in the same type rivers and with the quality requirements according to the WFD. 


\section{Materials and Methods}

\subsection{Study Area}

The San Xusto SHP station is situated in the middle reaches of the Lérez River, in the southwest of Galicia. The climate in the area is oceanic: the average annual rainfall is between $1246 \mathrm{~mm}$ (Pontevedra) and $2000 \mathrm{~mm}$ (Campolameiro) and the average temperature is $14.8^{\circ} \mathrm{C}[9,19]$.

River Lérez belongs to the Atlantic watershed of Galicia, and drains into the Ría de Pontevedra. It has a total length of $57 \mathrm{~km} \mathrm{[20]} \mathrm{and} \mathrm{its} \mathrm{flow} \mathrm{is} 14.4 \mathrm{~m}^{3} / \mathrm{s} 3 \mathrm{~km}$ downstream the SHP station and $21.2 \mathrm{~m}^{3} / \mathrm{s}$ in the river mouth [21]. The flow regime of the water flows in Galicia is related with the rainfall distribution [10]. The periods of highest flow is between December and March, and minimum occurs in September and the bedrock of the watershed is mainly granitic [21] leading to low water conductivity and low $\mathrm{pH}$ [22]. Natural vegetation in the riversides is Atlantic deciduous forest with oak (Quercus robur), black alder (Alnus glutinosa), willow (Salix atrocinerea), hazel tree (Corylus avellana), elder (Sambucus nigra) and ash (Fraxinus sp.). This forest is narrow and restricted to the river banks due to the pressure of other productive uses of the land as eucalyptus (Eucalyptus globulus) plantations and pastures, as well as the spread of invasive species as Acacia melanoxylon and Acacia dealbata.

The Lérez stream has been classified as salmonid waters [23], i.e., waters which support or become capable of supporting fish belonging to species such as salmon (Salmo salar), trout (Salmo trutta), or other species in other areas of Europe (Directive 2006/44/EC [24]). Currently, there is a population of salmon inhabiting the Lérez after being close to extinction early in the 1990s [25]. The stretch of the river where the San Xusto SHP plant is situated has been classified as CEDEX type 21: Cantabric-Atlantic siliceous rivers [26].

The human population density in municipality where this reaches of the river belongs is 32.1-32.9 inhabitants $/ \mathrm{km}^{2}$, but the neighbouring municipality of Pontevedra has 693 inhabitats $/ \mathrm{km}^{2}$ [27], so a recreational use of the river downstream the SHP station as well as a conservationist concern exists. Some fishing grounds exist both downstream and upstream the dam [21].

\subsection{Small Hydroelectric Power Station and River Lérez Reach}

The San Xusto SHP station is made up of a diversion dam, to block the river and divert the water, a pipeline which draws the water from a high level to the powerhouse, a penstock and a powerhouse building (Figure 1).

The dam has a fish ladder, which was completed in November 2006. The dam (UTM: 29T 541585; 4708041; $153 \mathrm{~m}$ above sea level (a.s.1.)) coronation has a length of $53 \mathrm{~m}$ and a height of $164 \mathrm{~m}$ a.s.1. and $11.05 \mathrm{~m}$ above the river. The surface of the water in the reservoir is $160 \mathrm{~m}$ high. The diversion pipe is $1960 \mathrm{~m}$ long and the penstock is $116 \mathrm{~m}$ long. The length of the river stretch between the dam and the tailrace is $3400 \mathrm{~m}$. The power house (UTM: 29T 539412; 4708029; $83 \mathrm{~m}$ a.s.1.) has 2 turbines of $10 \mathrm{~m}^{3} / \mathrm{s}$ and $5.91 \mathrm{MW}$ each. The gross head is $70 \mathrm{~m}$. The discharge is $20 \mathrm{~m}^{3} / \mathrm{s}$. and the station takes $59 \%$ of the water flow. The power is $11.81 \mathrm{MW}$ and the total production is $37.81 \mathrm{GWh} /$ year. 
Figure 1. Map of the elements of the San Xusto Small hydropower (SHP) plant on river Lérez.

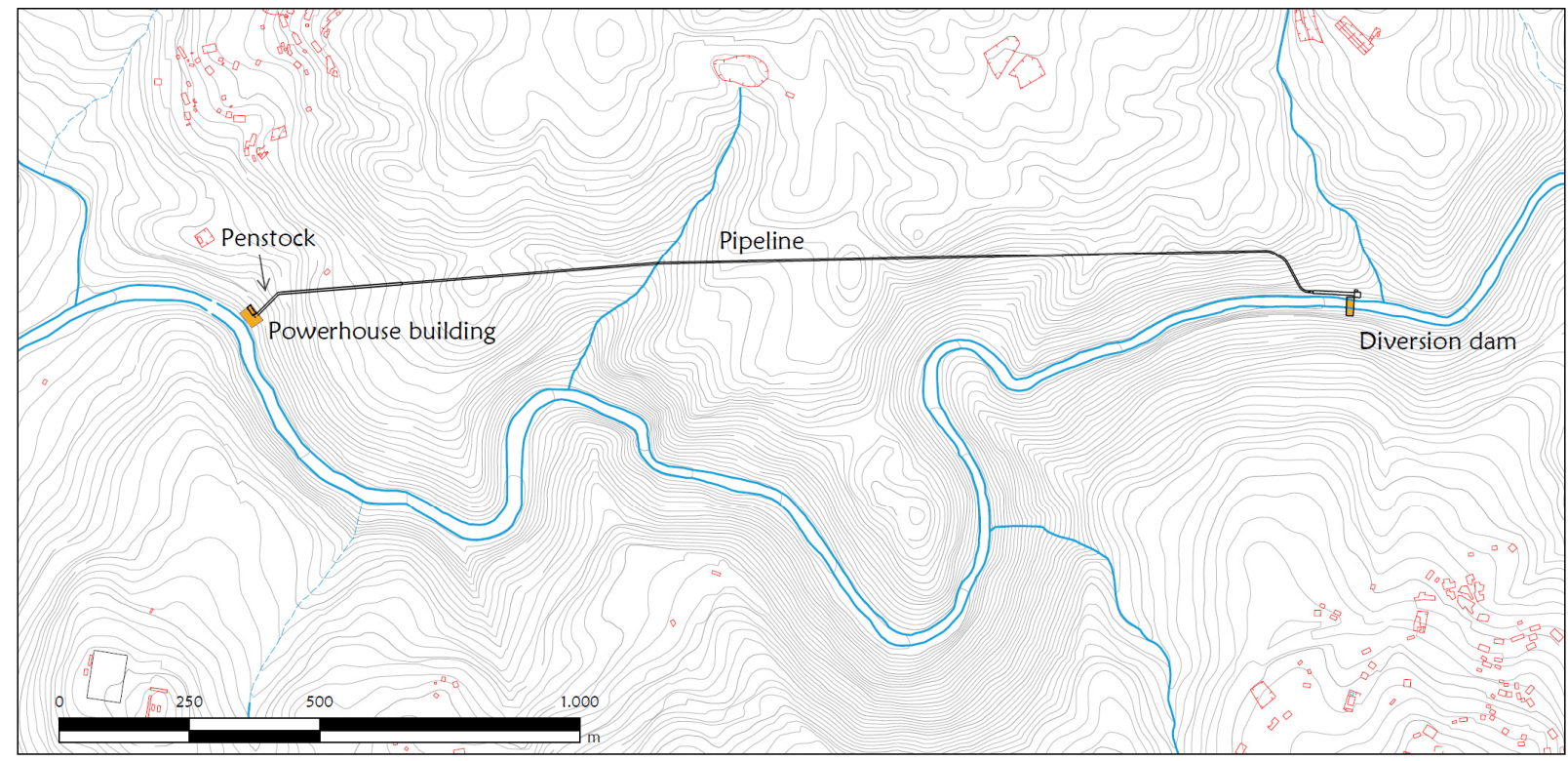

\subsection{Environmental Parameters, Water Status Indicators and Quality Criteria}

The Water Framework Directive 2000/60/EC (WFD) [17] was created to maintain and improve the aquatic environment in the EU countries. According to its article 2, the surface water status should be determined by its ecological and its chemical status. WFD establish that Member States shall ensure the establishment of programs to monitor the water status, which for surface waters shall cover: the volume and level of flow and the ecological and chemical status. WFD Annex V of [17] include the quality elements suggested for the classification of the ecological status of the surface water, including biological, hydromorphological and physicochemical elements, as well as criteria for definition of ecological status using that elements. Although these programs should be developed by the regional administrations, the indicators established by the WFD are useful to assess the water status that should be ideally achieved in reaches affected by small hydropower. Consequently, some of the water quality elements, established by WFD, have been taken in consideration in this work.

In order to describe the quality of the aquatic ecosystem in a river stretch including the San Xusto SHP station of the Lérez River, the physicochemical characteristics of the water, the biological quality of the water, and the ecological quality of riparian habitat were considered (Figure 2).

Between several chemical and physicochemical elements described in Annex V of WFD, the following physicochemical parameters were considered: water temperature $\left({ }^{\circ} \mathrm{C}\right)$, conductivity $(\mathrm{mS} / \mathrm{cm})$, dissolved oxygen (DO, mg/L), and $\mathrm{pH}$. It was used a handheld multiparameter instrument YSI 556MPS (YSI, Yellow Springs, OH, USA), accompanied by the following sensors types: YSI Temperature Precision $^{\mathrm{TM}}$ thermistor, 4-electrode cell with auto ranging, steady state polarographic, platinum button, glass combination electrode (see specifications in [28]). According to WFD, physicochemical conditions are considered good if the parameters do not reach levels outside the range established to ensure the functioning of the specific type of ecosystem. Then, the ranges established for salmonid waters in Directive 2006/44/EC [24] on the quality of fresh waters needing protection or improvement in order to support fish life were considered. The values registered for the parameters were compared 
with those registered in the closest station belonging to the Water Quality Control Network from Aguas de Galicia, as well as with the reference condition in Cantabric-Atlantic siliceous rivers (CEDEX type 21: Instrucciones de Planificación Hidrológica, henceforth IPH 2008 [29]).

Figure 2. (a) Schematic overview of the methodology; (b) environmental characteristics assessed, parameters and index used, and location of the sampling points (grey circles) and riparian habitat sections where the QBR (riparian forest quality index ) was calculated (red).
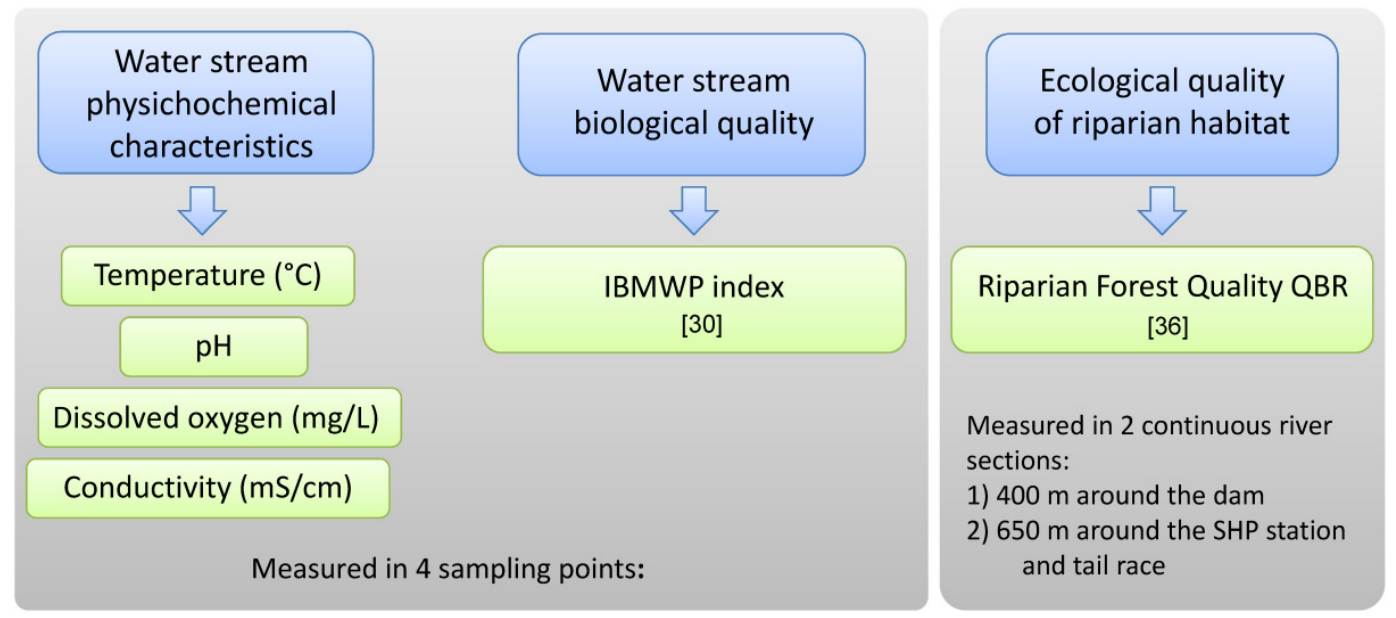

(a)

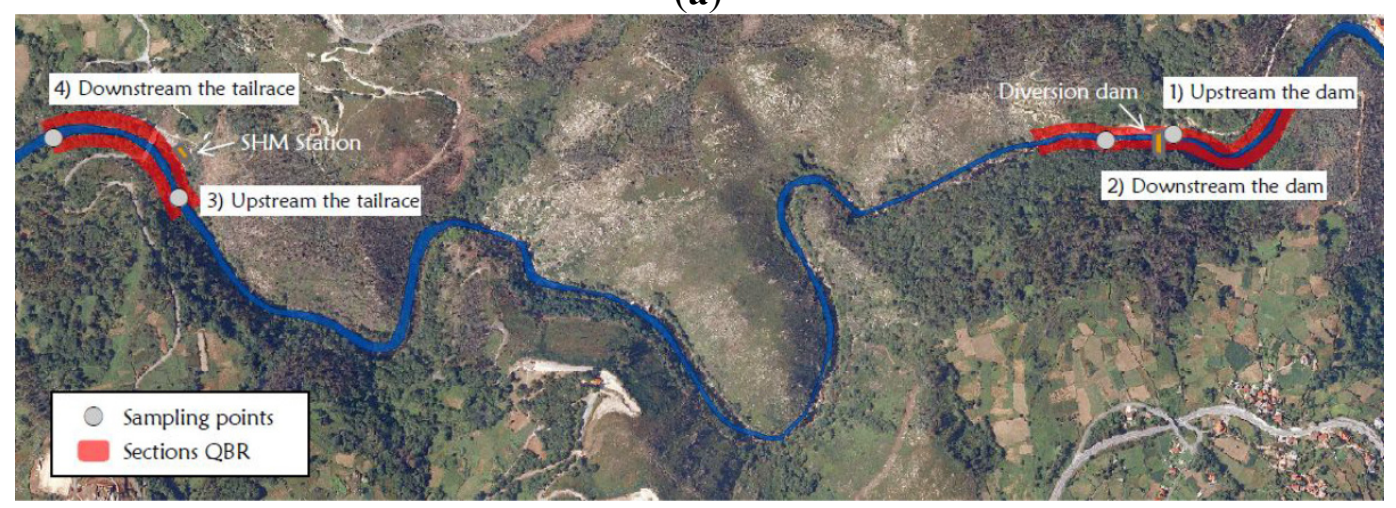

(b)

According to WFD, biological elements that should be taken in consideration in order to define the ecological quality are: composition and abundance of aquatic flora, composition and abundance of benthic invertebrate fauna and composition, abundance and age structure of fish fauna. The biological quality of the water was assessed using the index Iberian Biological Monitoring Working Party IBMWP [30,31]. This index is widely accepted and extensively used in Spain. It has been adapted from the British Biological Monitoring Working Party BMWP to the Iberian macroinvertebrates [30]. It is also easily applicable: the taxa of machobenthonic fauna found in the stream is identified to family level, a predefined score is allocated for each family and the total IBMWP score for a sample is a summation of the scores of all the families found. The scores of the IBMWP $(0->100)$ have been grouped in 5 quality classes [30]. Other index as NFAM (number of families) and IASPT (Iberian Average Score per Taxon) [26,32] were also obtained. The Equivalent Quality Ratio (EQR) was obtained [33,34]. IBMWP was scored according to [30] and was compared with the reference conditions in Cantabric-Atlantic 
siliceous rivers [35]. The WFD defines reference conditions as the values of biological, hydromorphological and physical-chemical quality elements at high ecological status.

Between the hydromorphological characteristics, high status is found weather the hydrological regime, river continuity, morphological conditions, structure and condition of the riparian zones correspond totally or nearly totally to undisturbed conditions. Nevertheless, when dealing with SHP stations, alterations occur. In this case good status is achieved if the hydro morphologic conditions are consistent with the achievement of the values specified above for the biological quality.

Although measures of the conservation status of riparian habitat are not often used to describe river health [36], the SHP building can affect the characteristics of the vegetation in the banks of the river. The Riparian Forest Quality or QBR index [36] has been used to assess the ecological quality of the riparian habitat in the reaches affected by the SHP plant construction. The index QBR varies between 0 and 100 and it is based on four components of riparian habitat: total riparian vegetation cover, cover structure, cover quality and channel alterations for the different geomorphology of the river from its headwaters to the lower reaches. After completing the analysis, the sum of scores for the four components gives the final QBR index.

\subsection{Sampling and Methodology}

In order to measure the physicochemical parameters of the water, 4 sampling points have been selected in places where the entry does not entail risk and trying to select areas accessible in the future in spite of changes in the flow, building works or vegetation changes (Figure 2, Table 1). The position of the sampling points was registered with a GPS GPSMAP 60CSx (Garmin, Olathe, KS, USA) and pictures were taken to describe them. They were situated in a zone with no excessive sunshine, excessively high or low stream velocity and medium depth.

Table 1. Location of the sampling points and samples taken.

\begin{tabular}{|c|c|c|c|}
\hline Sampling points & Location & UTM & Sampling \\
\hline 1 & Upstream the dam & 29T 541617-4708067 & Physicochemical parameters \\
\hline 2 & Downstream the dam & 29T 541471-4708055 & $\begin{array}{l}\text { Physicochemical parameters } \\
\text { Biological index (stream section) }\end{array}$ \\
\hline 3 & Upstream the tailrace & 29T 539467-4707928 & $\begin{array}{l}\text { Physicochemical parameters } \\
\text { Biological index (stream section) }\end{array}$ \\
\hline 4 & Downstream the tailrace & 29T 539195-4708058 & $\begin{array}{l}\text { Physicochemical parameters } \\
\text { Biological index (stream section) }\end{array}$ \\
\hline
\end{tabular}

On each sampling point, the handheld multiparameter instrument was immersed in the watercourse and, after a stabilization of $20 \mathrm{~min}$, the instrument was keep registering during $20 \mathrm{~min}$ more in order to obtain representative data. Previous laboratory calibration was performed for all sensors following the procedures described by YSI Environmental [37].

For the biological characteristics of the water, a $50 \mathrm{~m}$ radius-river stretches around the described points 2-4 were sampled (Table 1, Figure 2). The position of the borders of these stretches was registered with a GPS and photos of the sampled stretches were taken. The protocol [38] was followed: in the sampling stretches selected, different types of habitats were identified according to depth, flow velocity, substratum, 
and vegetation; each habitat was sampled; captures were identified over a white tray on the field using an atlas and key [39] and putting back the identified individuals into the river. Benthos which could not be identified in the field were kept in bottles with alcohol $70 \%$ to be identified in the laboratory.

The QBR index was calculated following the protocol [36] with some modifications. A river stretch of $400 \mathrm{~m}$ around the dam, and another river stretch of $650 \mathrm{~m}$ around the SHP station and tail race were selected (Figure 2). These reaches were divided in sections with similar characteristics and we calculated QBR index for each one. Points between two sections with different QBR were located with GPS. The creators of the index [36] established that both river banks should be considered together. Nevertheless, since some SHP plant elements only affect one bank, we calculate one QBR index for each bank.

\subsection{Sampling Period and Frequency}

During the 36 months period between December 2007 and November 2010, all the points were sampled every 3 months for the physicochemical and biological water quality: in March, June, September/October and November/December. QBR index was calculated twice a year: once in March and once in September. For the physicochemical parameters we used data registered by the SHP station owners previously with the same methodology on points 1-4: in March and September 2005, March, August, September and November 2006, and September 2007.

\subsection{Analyses}

The software Ecowatch was used to download and process physicochemical data taken by the multiparameter instrument. When data was registered for more than $20 \mathrm{~min}$, the series was trimmed to 200 samples or 20 min. We calculated descriptive for each 20 min sampling series: mean, standard deviation, maximum and minimum.

In the laboratory, we identified the captured macroinvertebrates taxa to family level [38] using a glass Motic ST-37 20-80× (Motic, Xiamen, China).

The values of the mean physicochemical variables of the series registered in each sampling point, as well as the IBMWP index were plotted over time to assess if their values stabilized themselves across time, as well as to observe differences between points. Differences between years and points were analyzed using Kruskal-Wallis tests. $\mathrm{pH}$, temperature and DO were compared with extreme values allowed in salmonid waters (Directive 2006/44/EC [24]). Values of pH, temperature, DO and conductivity were compared with those registered during the same time of the year in the closest river Lérez Station 14RW03070 [40] from the Water Quality Control Network belonging to Augas de Galicia, which is situated $2.4 \mathrm{~km}$ downstream the Power Station. IBMWP scores were classified according to [30]. Physicochemical variables and biological index were compared with the Reference Condition in Cantabric-Atlantic siliceous rivers from IPH 2008 and [35].

\section{Results and Discussion}

\subsection{Physicochemical Characteristics of the Water}

The physicochemical parameters $\mathrm{pH}$, temperature, dissolved oxygen, and conductivity did not show statistically significant differences between sampling points (Table 2). Previous studies neither 
observed significant influence of the presence of SHP plants on the physical and chemical quality of the water $[13,41]$.

Table 2. Physicochemical parameters of the water: mean and standard deviation values in the four sampling points for the study period (2007-2010), as well as Kruskal-Wallis test for the resulting differences.

\begin{tabular}{|c|c|c|c|c|c|c|c|c|c|}
\hline \multirow{2}{*}{ Parameters } & \multicolumn{2}{|c|}{ Point 1} & \multicolumn{2}{|c|}{ Point 2} & \multicolumn{2}{|c|}{ Point 3} & \multicolumn{2}{|c|}{ Point 4} & \multirow{2}{*}{ Kruskal-Wallis test } \\
\hline & Mean & SD & Mean & SD & Mean & SD & Mean & SD & \\
\hline $\mathrm{pH}$ & 5.97 & 0.56 & 5.98 & 0.34 & 6.15 & 0.30 & 5.99 & 0.76 & $2.452, p=0.484$ \\
\hline Temperature $\left({ }^{\circ} \mathrm{C}\right)$ & 12.10 & 3.90 & 12.43 & 3.91 & 12.89 & 3.95 & 12.27 & 4.05 & $0.249, p=0.969$ \\
\hline Dissolved oxygen $(\mathrm{mg} / \mathrm{L})$ & 10.67 & 1.32 & 11.43 & 1.16 & 11.13 & 1.11 & 11.54 & 1.53 & $3.557, p=0.313$ \\
\hline Conductivity $(\mathrm{mS} / \mathrm{cm})$ & 0.040 & 0.013 & 0.037 & 0.005 & 0.038 & 0.005 & 0.040 & 0.010 & $0.642, p=0.887$ \\
\hline
\end{tabular}

3.1.1. $\mathrm{pH}$

The mean $\mathrm{pH}$ between all sampling points for the study period (2007-2010) was $6.02(\mathrm{SD}=0.52$; $\mathrm{n}=50)$. $\mathrm{pH}$ was not statistically different between spring-summer (mean $=6.03$; $\mathrm{SD}=0.33$ ) and autumn-winter (6.02; $\mathrm{SD}=0.66$; Mann-Whitney $\mathrm{U}=315.500 ; p=0.946 ; \mathrm{n}=50)$, although higher $\mathrm{pH}$ values during the hottest months are usual [13]. The low $\mathrm{pH}$ values obtained (Table 2) can be related to a large extent to the natural characteristics of the stream waters in Galicia, which are acid due to the granitic substrate. The geological substrate of the watershed is the main factor constraining the physicochemical characteristics of unpolluted watercourses in Galicia [10]. In river Tea, Pontevedra Province, mean annual $\mathrm{pH}$ observed was 6.18 [42], while in Galician rivers with low mineralization via marine influence mean values of 6.6 (range $=5.2-7.1$ ) were observed [22]. In the stretch of river Lérez studied $\mathrm{pH}$ values were lower to those observed by these authors.

According to Directive 2006/44/EC [24], artificial pH variations with respect to the unaffected values shall not exceed \pm 0.5 of a $\mathrm{pH}$ unit within the limits falling between 6.0 and 9.0 provided that these variations do not increase the harmfulness of other substances present in the water. We have observed low $\mathrm{pH}$ values in the 4 sampling points (Table 2, Figure 3), close to the lower limit allowed for salmonid water: 6 (Directive 2006/44/EC). The $\mathrm{pH}$ observed were also lower than the $\mathrm{pH}$ values registered in the Aguas de Galicia Water Quality Control Station situated $2.4 \mathrm{~km}$ downstream (mean $=6.7$; SD $=0.3$; $\mathrm{n}=15$; period 2007-2011). Comparing to Reference Condition (Table 3), the water quality in the river stretch was classified according with its $\mathrm{pH}$ as moderate water condition.

During the SHP infrastructures and station construction (November 2006) and in the first year after, $\mathrm{pH}$ values were unbalanced. In the construction phase, $\mathrm{pH}$ decreased to values around 5 and the lower limits allowed for salmonid water (Directive 2006/44/EC [24]) were exceeded (Figure 3). In December 2007, pH soared to values higher than 7.5, which is a high value for rivers from Galician granitic watersheds [21]), but during the construction phase could be related with the contact of river water with concrete, cement, or other construction materials, containing calcium hydroxide, which is a caustic agent. Differences of $\mathrm{pH}$ between years were statistically significant only if 2007 is included in the analysis (Kruskal-Wallis test $=9.550 ; \mathrm{df}=3 ; p=0.023 ; \mathrm{n}=50$ ). No significant variation was observed in the $\mathrm{pH}$ between points (Table 2), although $\mathrm{pH}$ at point 3 (before the station and the tailrace) was usually higher than in point 4 (downstream the tailrace) (Table 2, Figure 3 ). We observed 
the higher, most acceptable, $\mathrm{pH}$ values in point 3 , before the tailrace, which could be related to the riverbed conditions at this point.

Table 3. Reference condition in Cantabric-Atlantic siliceous rivers according to [35], or according to IPH 2008 [29] those marked with *.

\begin{tabular}{lccc}
\hline \multicolumn{1}{c}{ Parameters } & Reference condition & Threshold good/moderate & Threshold moderate/bad \\
\hline Temperature $\left({ }^{\circ} \mathrm{C}\right)$ & 13.00 & $10.4-15.6$ & -- \\
Conductivity $(\mu \mathrm{S} / \mathrm{cm}) *$ & 40.00 & $<300$ & - \\
Dissolved oxygen $(\mathrm{mg} / \mathrm{L}) *$ & 9.00 & 6.70 & - \\
$\mathrm{pH}^{*}$ & 7.00 & $6.0-8.4$ & 20.20 \\
$\mathrm{IBMWP}$ & 230.00 & 162.00 & 3.20 \\
$\mathrm{NFAM}$ & 37.00 & 25.50 & 0.60 \\
$\mathrm{IASPT}$ & 6.30 & 4.40 & \\
\hline
\end{tabular}

Figure 3. $\mathrm{pH}$ values measured through the survey period whose start is showed by a blue arrow. SHP station construction time is showed as the orange arrow. In red, $\mathrm{pH}$ range allowed for salmonid water (Directive 2006/44/EC [24]). In black, pH values measured in the Water Quality Control Station.

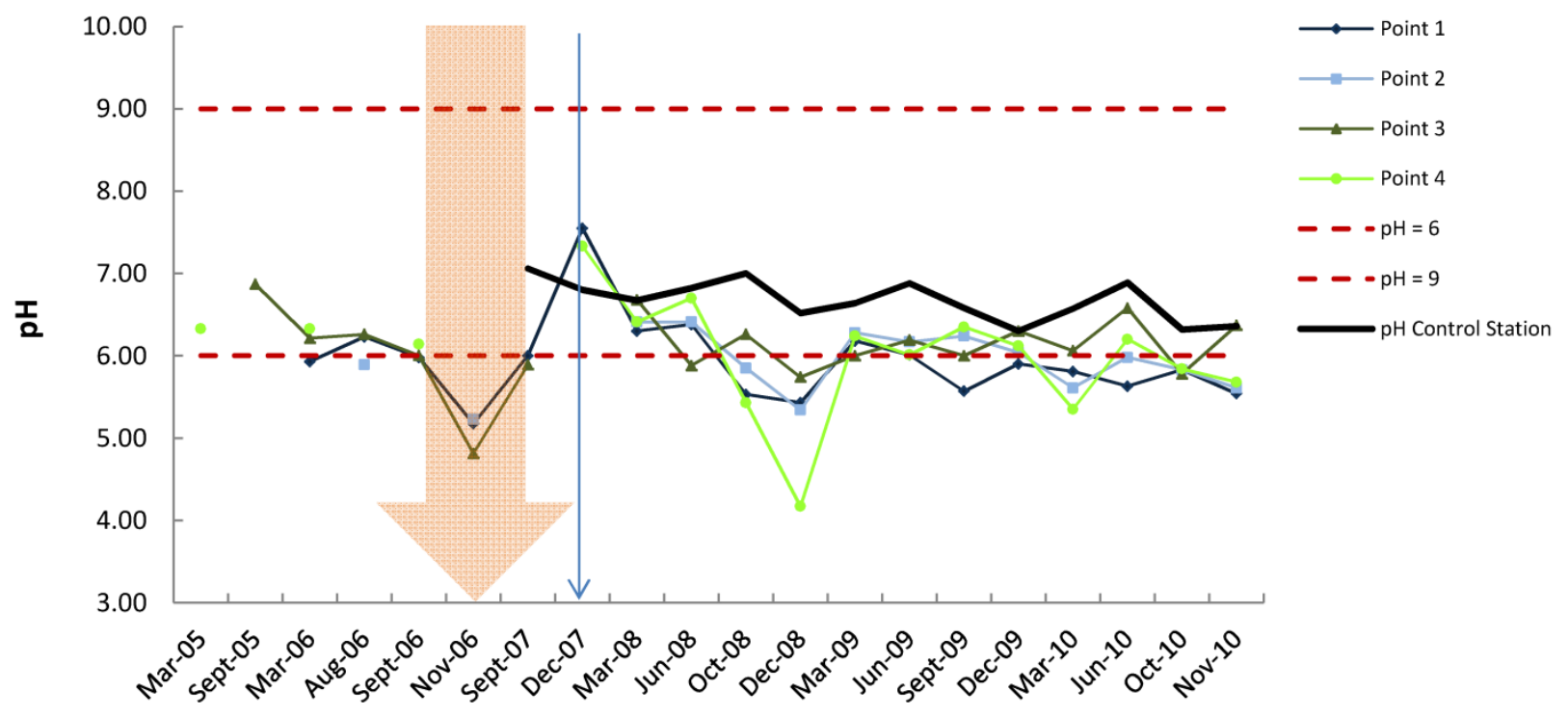

\subsubsection{Temperature}

Mean water temperature for the study period was $12.41(\mathrm{SD}=3.84 ; \mathrm{n}=50)$. This value was slightly lower than the temperature registered in the Aguas de Galicia Water Quality Control Station for the same period $($ mean $=13.37 ; \mathrm{SD}=3.37 ; \mathrm{n}=14$ ). Temperature values were close to Reference Condition (Table 3). Slightly higher temperatures were registered in points 2 and 3 than in the remaining sampling points, although statistically significant differences were not found between sampling points (Table 2). The mean water temperature was $8.92(\mathrm{SD}=0.97 ; \mathrm{n}=26)$ in autumn-winter and $16.19(\mathrm{SD}=1.35 ; \mathrm{n}=24)$ in spring-summer (Mann-Whitney $\mathrm{U}=236.50 ; p<0.001 ; \mathrm{n}=50$ ). Figure 4 show seasonal variation of the temperature. In river Tea, the mean annual water temperature registered was $14.0{ }^{\circ} \mathrm{C}$, with maximum values in August-September $\left(19.8^{\circ} \mathrm{C}\right)$ and minimum between 
November and January $\left(9.3{ }^{\circ} \mathrm{C}\right)$ [42]; thus, more extreme values than those registered by us in the San Xusto SHP station, probably due to the more extreme air temperatures in river Tea.

Figure 4. Water temperature $\left({ }^{\circ} \mathrm{C}\right)$ through the survey period whose start is shown by a blue arrow. SHP station construction time is shown by the orange arrow. The red line and points indicate the upper temperature limit which should not be exceeded in salmonid waters (Directive 2006/44/EC [24]).

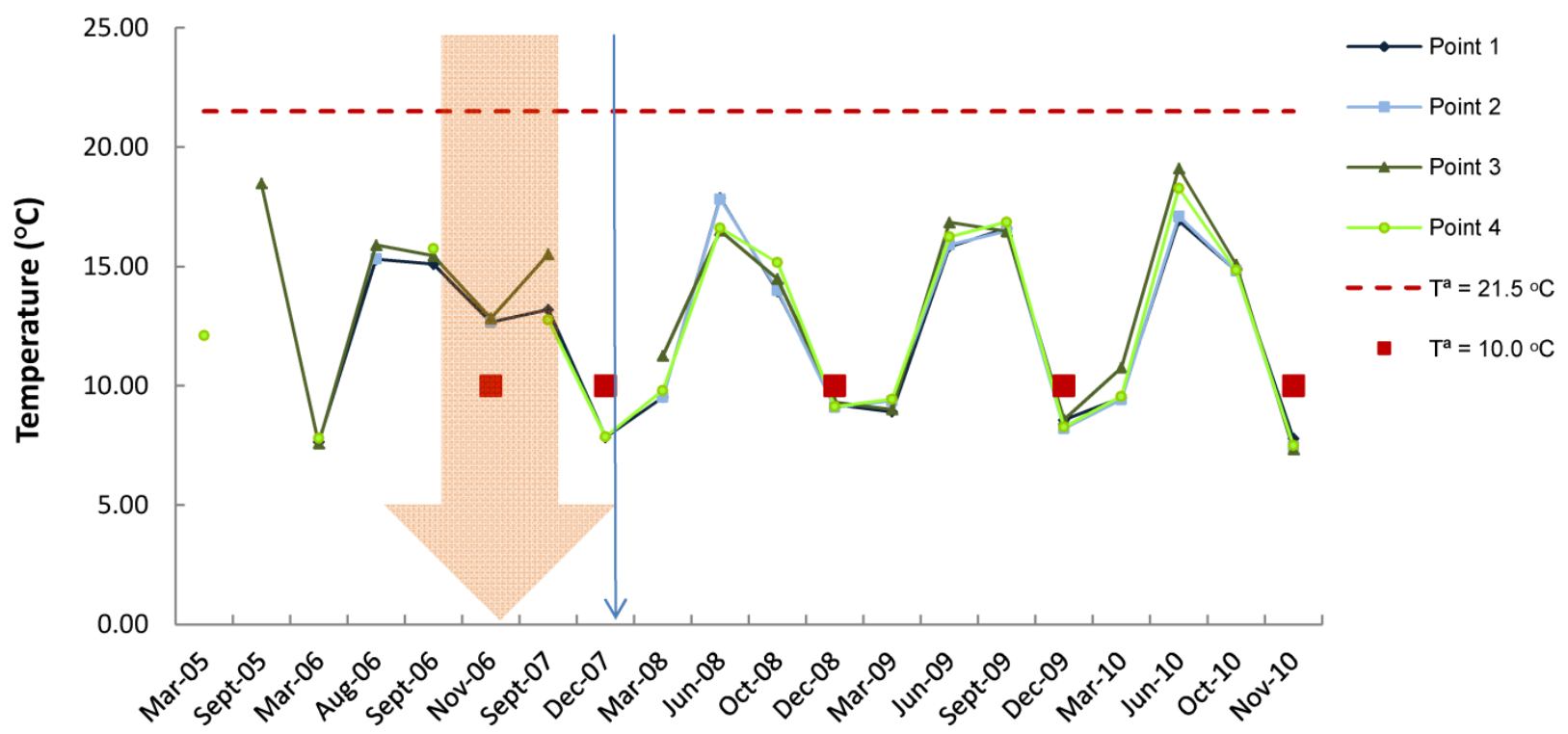

According to Directive 2006/44/EC [24], thermal discharges must not cause the temperature downstream of the point of thermal discharge to exceed $21.5^{\circ} \mathrm{C}$ in salmonid waters. This temperature limit was not exceeded in any sampling point for any season (Figure 4). In the same way, Directive 2006/44/EC lays down that water temperature measured downstream a thermal discharge cannot exceed $10{ }^{\circ} \mathrm{C}$ during breeding periods of species which need cold water for reproduction in waters which may contain such species. Therefore, for salmon in Galicia, whose reproductive season is between November and January [20], temperature values from the sampling carried out in those months should not exceed $10{ }^{\circ} \mathrm{C}$. Temperature registered in all samplings between November and January was $<10^{\circ} \mathrm{C}$, although during the SHP station construction, temperature in points $1-3$ exceeded this value (Figure 4). The temperature of the water before (point 3) and after (point 4) the tail race did not showed significant difference (Mann-Whitney $\mathrm{U}=73.00 ; \mathrm{p}=0.786 ; \mathrm{n}=25$ ) and the increment was below $1.5{ }^{\circ} \mathrm{C}$ during the sampling period, so it fulfilled the requirement of Directive 2006/44/EC [24]: temperature measured downstream of a point of thermal discharge must not exceed the unaffected temperature in more than $1.5{ }^{\circ} \mathrm{C}$. The water temperature difference between points 4 and 3 was usually $<0$, which indicate that the pass of water through the pipes and turbines results in a slight decrease of temperature. This is probably caused by water circulating through subterranean pipes.

\subsubsection{Dissolved Oxygen}

Mean dissolved oxygen in the river stretch studied was $11.19 \mathrm{mg} / \mathrm{L}(\mathrm{SD}=1.30 ; \mathrm{n}=50)$. It was higher in autumn-winter $(11.93 \mathrm{mg} / \mathrm{L} ; \mathrm{SD}=1.11 ; \mathrm{n}=26)$, coinciding with maximum flow and minimum temperature, than in spring-summer (mean $=10.39 \mathrm{mg} / \mathrm{L} ; \mathrm{SD}=0.99 ; \mathrm{n}=24$ ) 
(Mann-Whitney $\mathrm{U}=624.00 ; p<0.001 ; \mathrm{n}=50$ ), being that dissolved oxygen is inversely related to temperature and directly related with the water flow [13]. A lower value of annual mean DO was observed in river Tea: $9.6( \pm 0.2) \mathrm{mg} / \mathrm{L}$ with maximum values between January and February $(11.0 \pm 0.2 \mathrm{mg} / \mathrm{L})$ and minimum between August and September $(7.9 \pm 0.4 \mathrm{mg} / \mathrm{L})$ [42]. DO value was minimum in sampling point 1 (before the dam) as it was expected, and maximum in point 4 (downstream the tailrace) and point 2 (downstream the dam), although differences in dissolved oxygen between points were not statistically different (Table 2, Figure 5). DO explains the occurrence of fish communities [42] so it is a basic parameter to asses water quality. DO values in all the sampling points were higher than the one observed in river Tea [42]. In comparison with Reference Condition the values registered in San Xusto were also higher (Table 3).

Figure 5. Dissolved oxygen $(\mathrm{mg} / \mathrm{L})$ through the survey period whose start is shown by a blue arrow. SHP station construction time is shown by the orange arrow. The red line indicates the limit which should not be exceeded in salmonid waters (Directive 2006/44/EC [24]). In black, DO values measured in the Water Quality Control Station.

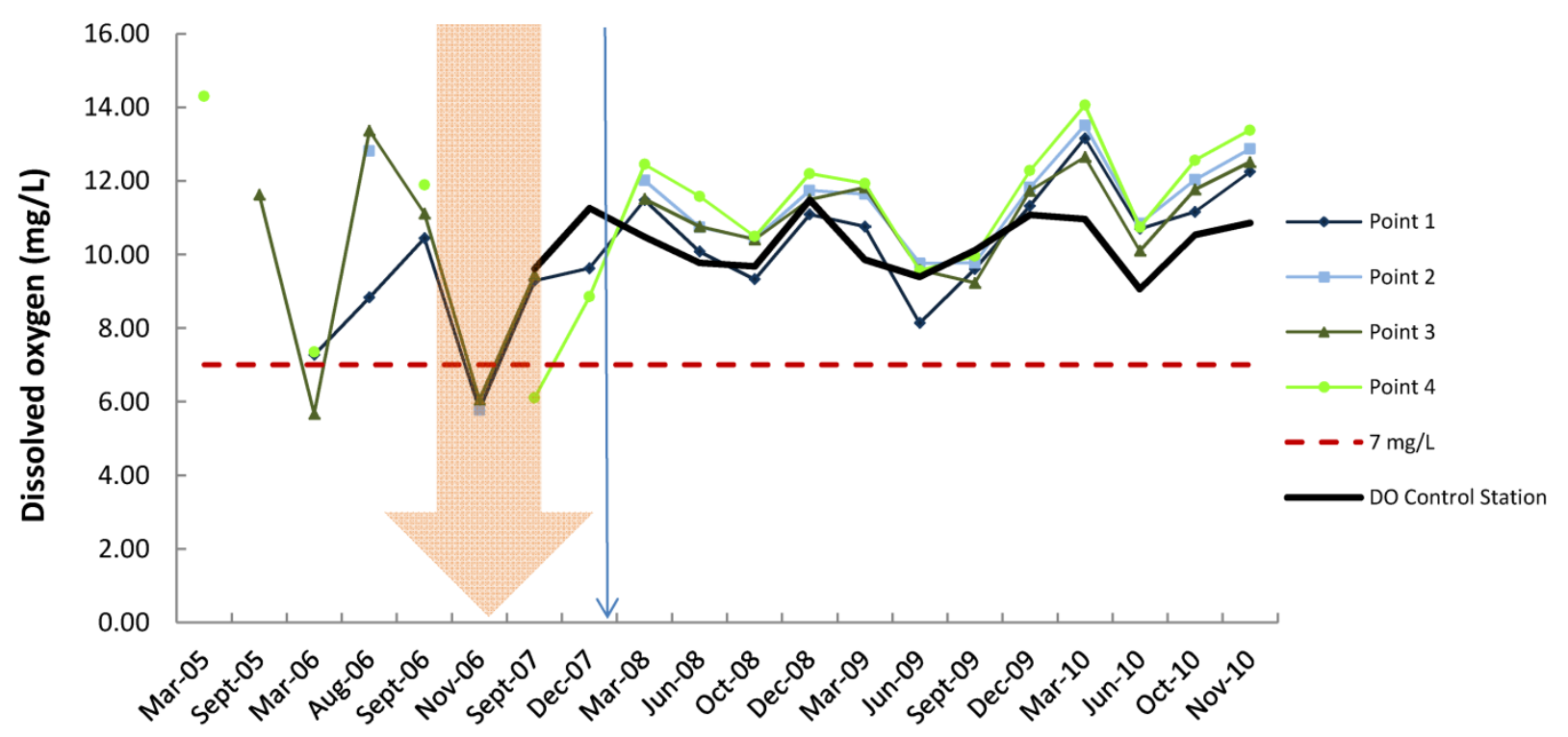

On the Water Quality Control Station, DO presented fluctuations related to the seasonal flow changes, but stayed stable between years, whereas around San Xusto SHP station an increasing trend of the DO was observed (Kruskal-Wallis test $=15.742 ; \mathrm{df}=3 ; p=0.001 ; \mathrm{n}=50$ ) and values higher to those registered in the Water Quality Control Station (Figure 5). Usually SHP schemes have an effect decreasing the DO [43]. One of the environmental changes often associated with hydropower is the low dissolved oxygen content of the water released from hydropower reservoirs, especially during the summer and at large projects with deep reservoirs, low flushing rates, or warm climates [44]. In San Xusto SHP this problem was evident only during the construction phase, after which values increased.

During the SHP infrastructures and station construction (November 2006) the flow was minimum since the river was interrupted, which could explain the plunge of the dissolved oxygen in that time (Figure 5), when it fell down the allowed level for salmonids waters (Directive 2006/44/EC [24]). Since then, the dissolved oxygen values climbed (Figure 5), with minimum values in summer as a result of seasonal warming, staying always inside the limits allowed for salmonid water. 


\subsubsection{Conductivity}

Although significant changes in the conductivity were observed during the construction phase, 2 years after the conductivity values bounced back and remained constant around 0.03-0.04 mS/cm (Figure 6). The difference in conductivity between years was statistically significant (Kruskal-Wallis test $=21.436$; $\mathrm{df}=3 ; p=0.001 ; \mathrm{n}=50$ ). The values observed (mean $=37.60 \mu \mathrm{S} / \mathrm{cm}, \mathrm{SD}=4.76 ; \mathrm{n}=50$ ) are in the range of conductivity measured in other rivers in Galicia: $40.3 \pm 1.0 \mu \mathrm{S} / \mathrm{cm}$ in river Tea [42], $52 \mu \mathrm{S} / \mathrm{cm}$ for rivers with mineralization via marine influence in Galicia [10]. On the Water Quality Control Station, the conductivity was lower (mean $=35.18 \mu \mathrm{S} / \mathrm{cm}$; $\mathrm{SD}=3.24 ; \mathrm{n}=14$ ). Mean values registered in the river stretch studied were $2.4 \mu \mathrm{S} / \mathrm{cm}$ lower than the conductivity for the Reference Condition. The data suggest that water conductivity in the river stretch studied could has been altered by the construction of the SHP plant but after 2 year values were already inside de normal range, even closer to the Reference Condition than the Control Station situated $2.4 \mathrm{~km}$ downstream.

Figure 6. Conductivity $(\mathrm{mS} / \mathrm{cm})$ through the survey period whose start is shown by a blue arrow. SHP station construction time is shown by the orange arrow.

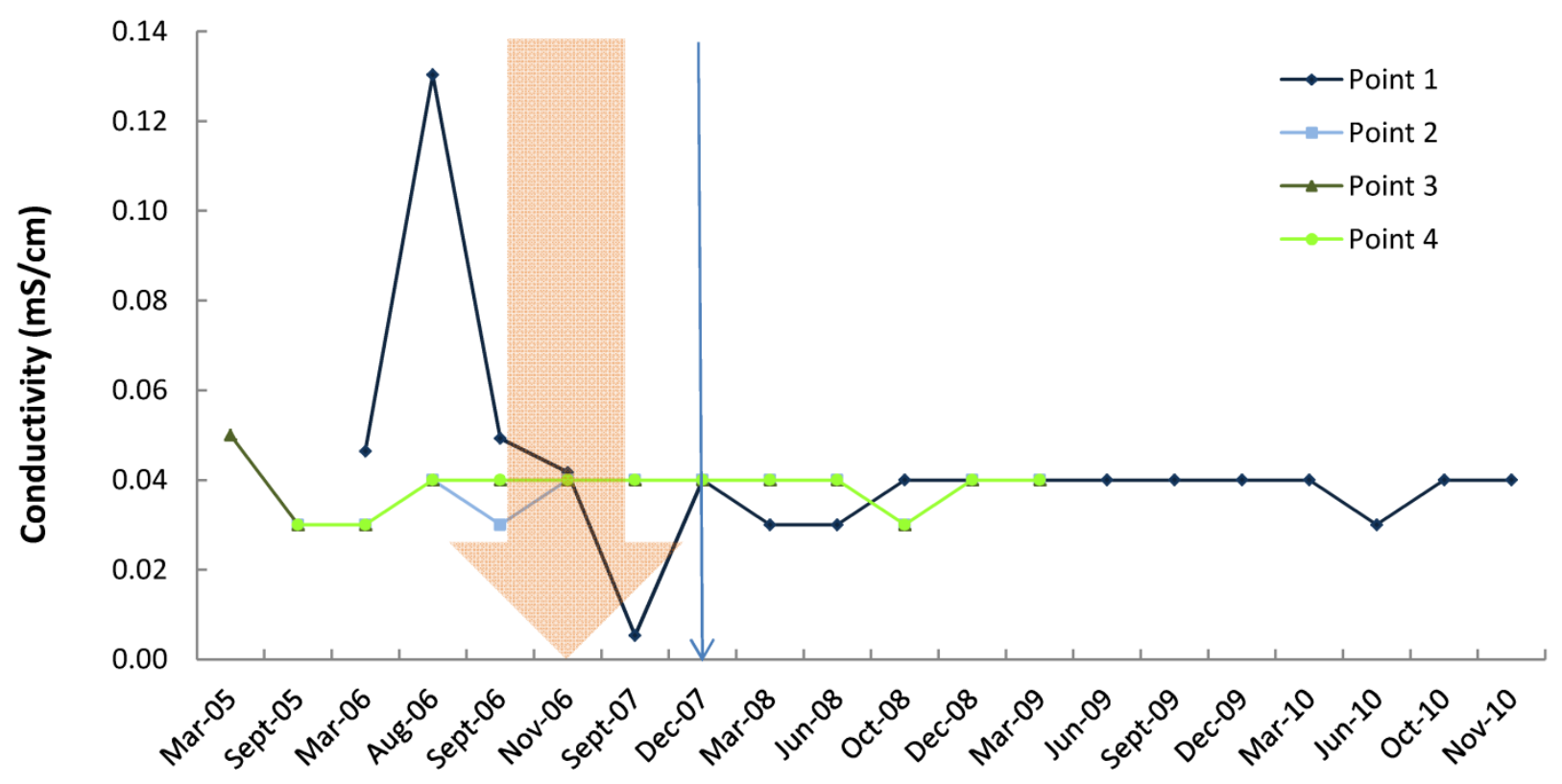

\subsection{Biological Status of the Water}

Lower scores for the IBMWP index were observed in point 3, upstream the power station (mean IBMWP $=110 ; \mathrm{SD}=26)$ compared with point $2($ mean IBMWP $=115 ; \mathrm{SD}=15)$ and point 4 (mean IBMWP $=114 ; \mathrm{SD}=30)$, although differences between points were not statistically significant (Kruskal-Wallis test $=1.756 ; \mathrm{df}=2 ; p=0.416 ; \mathrm{n}=37$ ).

Some studies did not observed severe adverse consequences on benthic macroinvertebrate community due to the SHP schemes [45,46], and even some observed a slight increase in the benthic fauna [46]. Others observed a lower density and specific richness of invertebrates in the points situated downstream the SHP plant compared to the points situated upstream [14]. Mean index during the study period were scored inside biological quality class I: unpolluted or not considerably altered water [30]. In a river stretch around a small hydroelectric power plan in the Ardena river (Portugal), the benthic macroinvertebrate 
communities have presented high richness, diversity and equitability [15]), although some decrease of the water quality and an alteration of the structure and composition of the benthic macroinvertebrate community due to the operation of a SHP plant was observed by these authors.

IBMWP index showed a positive trend from 2 years after the construction of the SHP plant and its values stabilized themselves on biological quality I. In December 2007, one year after the SHP station construction, only points 2 and 4 were sampled for biological status of the water. IBMWP in point 2 showed a score of 75 (quality II: some effects of pollution are evident) and in point 4 a score of 120 (quality I: unpolluted or not considerably altered water) (Figure 7). In March 2008, 16 months after the construction, the IBMWP scores observed in point 2 (downstream the dam) showed a water-biological quality II (moderate effect of pollution are evident), and scores observed in points 3 and 4 showed quality IV (very polluted water). Since this moment, when the worse biological quality of the waters were observed, biological conditions were improving until to the point, in December 2008, when the IBMWP scores on the three sampling points level off in status I (very clean waters and unpolluted or not considerably altered water). Nevertheless, our results suggest, that river stretches around SHP plants operational conserve the conditions for the development of well-structured biotic communities as well as observed in other works [13]. In this sense it was previously observed that in the aestival period, with the suspension of the operations of the small hydroelectric plant, there was an almost total recovery of the communities [13].

Figure 7. Evolution of the water biological quality index IBMWP during the period of study: I (>120) very clean waters; I (101-120) unpolluted or not considerably altered water; II (61-100) moderate effects of pollution are evident; III (36-60) polluted water; IV (16-35) very polluted water; V $(<15)$ guspolluted water.

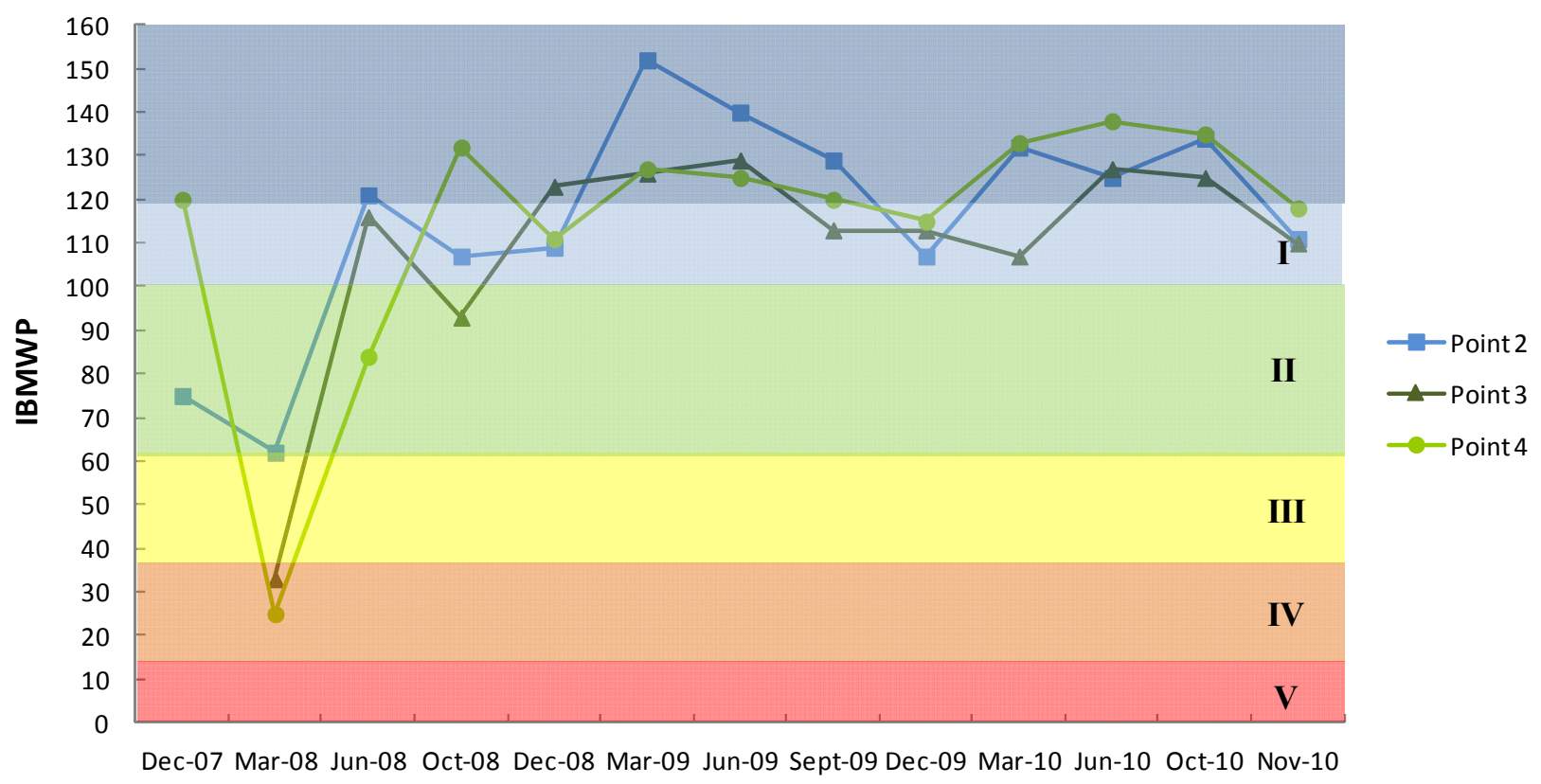

For the rivers classified as type 21, reference conditions related with IBMWP has not been defined in the IPH 2008. So, in order to classify the biological quality of the water, the ecological index were compared with the reference condition given by [35] (Table 4). The IBMWP EQR was calculated and compared with the IPH 2008 limits of the river type which was considered more similar and for which 
IPH 2008 provide reference conditions for (rivers type 25: IPH 2008). The river Lérez stretch studied showed an unfavourable ecological status according with [35], or a moderate ecological quality according with IPH 2008, except for the year 2008 when it was deficient (EQR $<0.42$, Table 4). The NFAM show a unfavourable status every year [35]. Nevertheless, IASPT showed higher values than the reference condition and EQR $>1$. These results suggest that the diversity of macrobenthos in this stretch of the river around the San Xusto SHP plant is lower than the reference condition, but the present families have high ecological value. This effects had been described previously [45]) in Wales, where these authors also obtained a low score of the index BMWP but the taxa present indicated good quality, thus giving a reasonable ASPT.

Table 4. Ecological index IBMWP, NFAM (number of families), IASPT (Iberian Average Score per Taxon) per year in the stretch of river studied, compared to the Reference Condition in Cantabric-Atlantic siliceous rivers using the EQR (Equivalent Quality Ratio).

\begin{tabular}{lccccc}
\hline \multirow{2}{*}{ Index } & Reference condition & \multicolumn{4}{c}{ San Xusto SHP plant } \\
\cline { 3 - 6 } & River type 21 & $\mathbf{2 0 0 7}$ & $\mathbf{2 0 0 8}$ & $\mathbf{2 0 0 9}$ & $\mathbf{2 0 1 0}$ \\
\hline IBMWP & 230.00 & 120.00 & 92.25 & 123.83 & 124.58 \\
EQR-IBMWP \% & & 0.52 & 0.40 & 0.54 & 0.54 \\
NFAM & \multirow{2}{*}{37.00} & & 13.75 & 18.33 & 18.58 \\
EQR-Taxa \% & & & 0.37 & 0.50 & 0.50 \\
IASPT & \multirow{2}{*}{6.30} & & 6.75 & 6.76 & 6.73 \\
EQR-IASPT \% & & & 1.07 & 1.07 & 1.07 \\
\hline
\end{tabular}

Biological status relies also on the composition, abundance and age structure of fish fauna. Moderate status occurs when the composition and abundance of fish species differ moderately from the type-specific communities attributable to anthropogenic impacts on physico-chemical or hydromorphological quality elements (Directive 2000/60/EC, Annex V. 1.2.1 [17]). The San Xusto SHP plant incorporates a fish ladder, managed by the regional government (Xunta de Galicia). This ladder, if used, would reduce the negative impact of the dam on the fish population [11], but we registered no use of this ladder and consequently a probable effect of the dam on the fish population. Diversion dams of SHP plant hinder the passage of eels $[47,48]$ ), and also alter the populations of other fish species $[41,46,49]$. Some authors $[41,46]$ found differences in population size-structure among sites upstream and downstream from SHPs with suitable fish passes for Barbus bocagei and Squalius carolitertii, as well as for B.bocagei, S. carolitertii and Salmo trutta in SHPs with unsuitable fish passes. Specifically there have been observed a change in the structure of fish assemblages when comparing before and after SHP plant started to operate [49]. Elements of SHP plants, specially dams, are not always complete barriers for fish [50] even if they are fitted with no effective fish passes [41]. Mitigation measures, such as environmental flows and fish passage facilities made it possible to limit to some extent the negative impacts of the SHP plants, although every obstruction in the river, even fitted with effective fish passage facilities creates a delay in migration [12]. 


\subsection{Ecological Status of the Riparian Zones}

The evaluation of the riparian habitat showed two river bank sections with extreme degradation (QBR $\leq 25$, Figure 8): (1) a right bank stretch of $200 \mathrm{~m}$ situated around the dam, the diversion pipe and fish ladder; (2) a right bank stretch of $50 \mathrm{~m}$ where the power house is situated. Around the power house we observed a river stretch of $110 \mathrm{~m}$, on both river banks, with alterations from extreme degradation, on the power house, to important disturbance. In the remaining sections the riparian habitat was classified as good quality (QBR $=75-90)$, or even natural condition (QBR $\geq 95)$. SHP plant effect on riparian habitat was only observed in the sections affected by the constructions, totalling a stretch of $300 \mathrm{~m}$.

Figure 8. Riparian habitat quality index QBR [36] in the reaches affected by the SHP plant.

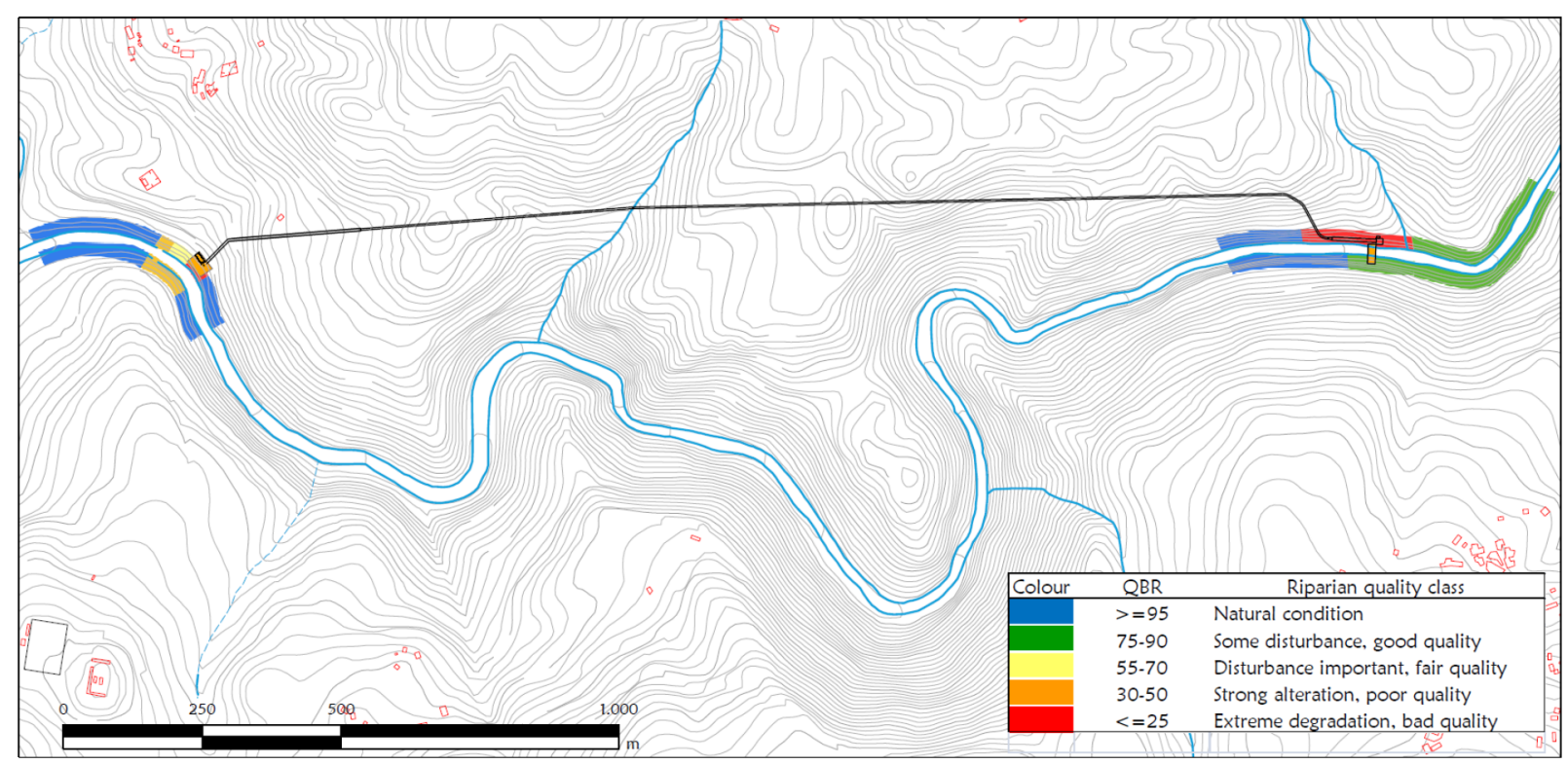

\section{Summary and Conclusions}

Our results suggest that SHP plant construction momentarily disturbed the physical-chemical characteristics of the water. It caused a $\mathrm{pH}$ destabilization, which fell to values $<5.5$ during the construction and soared to values unusually high in the second year after construction. At the same time, temperature exceeded the threshold value of $10{ }^{\circ} \mathrm{C}$ during breeding periods of salmo. The interrupted flow and the high temperatures of water caused a plunge in the dissolved oxygen, to below the allowed level for salmonids waters. Significant changes in conductivity were also observed during construction. However, two years after construction both temperature and dissolved oxygen values achieved conditions for normal development of the aquatic life, while $\mathrm{pH}$ values were close and even under the lower limit allowed for salmonid water: 6 (Directive 2006/44/EC [24]). No statistically significant differences were observed in the IBMWP between downstream the dam, upstream and downstream (tail race), suggesting no significant influence of the SHP scheme plant on the water's biological quality during operation. The IBMWP index showed a positive trend from two years after the construction of the SHP plant and its values stabilized on biological quality I. The IBMWP observed, suggest that the diversity of macrobenthos in this stretch of the river around the San Xusto SHP plant, is lower than the reference conditions, but the families present are of high ecological value. 
This suggests that the construction of the SHP plant caused an adverse effect in the ecosystem with respect of the physicochemical parameters and biological quality of the water. However, this was a transitory situation and, within two years, both physicochemical parameters and the biological quality of the water achieved conditions ecologically compatible, as has been observed in previous studies $[13,14,41]$. Some measures which could minimize the existing adverse environmental impacts are: decrease of land excavations and blasting during construction, assurance of maintaining minimal river flow downstream of the dam according to relevant legislation.

With respect to the riparian vegetation, the SHP scheme had a severe effect on the riparian habitat but this was only observed in the sections affected by the construction. In order to achieve a minimum effect on the riparian vegetation restoration of the vegetation is needed, i.e. replanting of trees species native to the area. For the visual integration of the constructions in the landscape, the SHP building and other elements should be constructed using rustic materials esthetically harmonized with the environment.

\section{Acknowledgments}

This work was possible thanks to the projects developed by the group AF4 for the company TASGA Renovables. Roberto Pérez Lodos and Juan Jesus Berzosa Aránguez from TASGA facilitated the work. I acknowledge Aguas de Galicia, especially Belén Quinteiro Seoane, Mónica Velo Cid and Raquel Piñeiro Rebolo, the information facilitated. The author is grateful to all the technicians participating in the samplings.

\section{References}

1. Tzimas, E.; Georgakaki, A.; Peteves, S.D. Future Fossil Fuel Electricity Generation in Europe: Options and Consequence; Joint Research Center, European Commission: Petten, The Netherlands, 2009. Available online: http://ec.europa.eu/dgs/jrc/downloads/jrc_reference_report_200907_fossil_ fuel_electricity.pdf (accessed on 10 July 2012).

2. Eurostat. Electricity Production And Supply Statistics. Available online: http://epp.eurostat.ec. europa.eu/statistics_explained/index.php/Electricity_production_and_supply_statistics (accessed on 5 March 2012).

3. Dincer, I. Renewable energy and sustainable development: A crucial review. Renew. Sustain. Energy Rev. 2000, 4, 157-175.

4. Míguez, J.L.; López-Gonzalez, L.M.; Sala, J.M.; Porteiro, J.; Granada, E.; Morán, J.C.; Juárez, M.C. Review of compliance with EU-2010 targets on renewable energy in Galicia (Spain). Renew. Sustain. Energy Rev. 2006, 10, 225-247.

5. Dincer, I.; Rosen, M.A. A worldwide perspective on energy, environment and sustainable development. Int. J. Energy Res. 1998, 22, 1305-1321.

6. Islam, M.; Fartaj, A.; Ting, D.S.K. Current utilization and future prospects of emerging renewable energy applications in Canada. Renew. Sustain. Energy Rev. 2004, 8, 493-519.

7. Paish, O. Small hydro power: Technology and current status. Renew. Sustain. Energy Rev. 2002, 6, 537-556. 
8. Thematic Network on Small Hydropower. Proposals for a European Strategy of Research, Development and Demonstration for Renewable Energy from Small Hydropower; The European Small Hydropower Association (ESHA): Brussels, Belgium, 2005. Available online: http://www. esha.be/publications/publications.html (accessed on 9 March 2012).

9. Martínez Cortizas, A.; Pérez Alberti, A. Climate Atlas of Galicia (in Spanish); Xunta de Galicia, Consellería de Medio Ambiente: Santiago de Compostela, Spain, 2000.

10. Martínez-Ansemil, E.; Membiela, P. The low mineralized and fast turnover watercourses of galicia. Limnetica 1992, 8, 125-130.

11. Larinier, M. Fish passage experience at small-scale hydro-electric power plants in France. Hydrobiologia 2008, 609, 97-108.

12. Abbasi, T.; Abbasi, S.A. Small hydro and the environmental implications of its extensive utilization. Renew. Sustain. Energy Rev. 2011, 15, 2134-2143.

13. Jesus, T.; Formigo, N.; Santos, P.; Tavares, G.R. Impact evaluation of the Vila Viçosa small hydroelectric power plant (Portugal) on the water quality and on the dynamics of the benthic macroinvertebrate communities of the Ardena river. Limnetica 2004, 23, 241-256.

14. Fu, X.; Wu, N.; Zhou, S.; Jiang, W.; Li, F.; Cai, Q. Impacts of a small hydropower plant on macroinvertebrate habitat and an initial estimate for ecological water requirement of Xiangxi river. Acta Ecol. Sin. 2008, 28, 1942-1948.

15. Fu, X.; Tang, T.; Jiang, W.; Li, F.; Wu, N.; Zhou, S.; Cai, Q. Impacts of small hydropower plants on macroinvertebrate communities. Acta Ecol. Sin. 2008, 28, 45-52.

16. Wu, N.C.; Jiang, W.X.; Fu, X.C.; Zhou, S.C.; Li, F.Q.; Cai, Q.H.; Fohrer, N. Temporal impacts of a small hydropower plant on benthic algal community. Fundam. Appl. Limnol. 2010, 177, 257-266.

17. Directive 2000/60/EC of the European Parliament and the Council of 23 October 2000 Establishing a Framework for Community Action in the Field of Water Policy; Official Journal of the European Communities: Brussel, Belgium, 2000.

18. Stalzer, W.; Bloch, H. Preface: The Austrian approach. Hydrobiologia 2000, 422-423, XIX-XXI.

19. Carballeira, A.; Devesa, C.; Retuerto, R.; Santillán, E.; Ucieda, F. Bioclimatology of Galicia (in Spanish); Fundación Pedro Barrie de la Maza: Vigo, Spain, 1983.

20. Xunta de Galicia. Galician Plan of Management of Fish Resources and Continental Acuatic Ecosystems (in Spanish); Xunta de Galicia: Santiago de Compostela, Spain, 2005.

21. Consellería do Medio Rural e do Mar. Espacios protegidos. ZEPVN Río Lérez Protected Areas. Areas with Special Protection of Natural Values. River Lérez; Xunta de Galicia: Santiago de Compostela, Spain, 2012. Available online: http://mediorural.xunta.es/es/areas/conservacion/ espazos_protexidos/rede_galega/zepvn/rio_lerez/ (accessed on 21 February 2012).

22. Membiela, P.; Montes, C.; Martínez-Ansemil, E. Hydrochemical characteristics of the rivers of Galicia (NW Iberian Peninsula) (in Spanish). Limnetica 1991, 7, 163-174.

23. Ministerio de Medio Ambiente. Manual of the Directive 78/659/CEE on the Quality of Fresh Waters Needing Protection or Improvement to Be Suitable for the Life of Fish (in Spanish); Ministerio de Medio Ambiente: Madrid, Spain, 2004. Available online: http://www.magrama.gob.es/es/agua /publicaciones/02_manual_directiva_78_659_cee_tcm7-28958.pdf (accessed on 1 February 2012). 
24. Directive 2006/44/EC of the European Parliament and of the Council of 6 September 2006 on the Quality of Fresh Waters Needing Protection or Improvement in Order to Support Fish Life; Official Journal of the European Communities: Brussel, Belgium, 2006.

25. Saura, M.; Caballero, P.; Caballero, A.; Moran, P. Genetic variation in restored atlantic salmon (Salmo salar L.) populations in the Ulla an Lérez rivers, Galicia, Spain. Ices J. Mar. Sci. 2006, 63, 1290-1296.

26. Aguas de Galicia and Consellería de Medio Ambiente, Territorio e Infraestructuras. Hydrological Plan-River Basin of Galicia-Costa. Chapter 2. Overview of the River Basin (in Spanish); Aguas de Galicia: Santiago de Compostela, Spain, 2010. Available online: http://www.planhidroloxicogc.com /web/documentacion (accessed on 13 June 2012).

27. Figures about Galicia: Population, Population Centers and Density (in Spanish); Instituto Galego de Estadística: Santiago de Compostela, Spain, 2010. Available online: http://www.ige.eu/igebdt/ selector.jsp?COD=4705\&paxina $=001 \& \mathrm{c}=0501$ (accessed on 23 February 2012).

28. YSI 556 Multiparameter System Specifications; YSI Environmental: Yellow Springs, OH, USA, 2009. Available online: http://www.ysi.com/media/pdfs/ (accessed on 16 February 2012).

29. Ministerio de Agricultura, Alimentación y Medio Ambiente. ORDEN ARM/2656/2008, de 10 de septiembre, por la que se aprueba la instrucción de planificación hidrológica. Boletín Oficial del Estado 2008, 229, 38472-38582; BOE-A-2008-15340.

30. Alba-Tercedor, J.; Sánchez-Ortega, A. A simple and quick method to evaluate the biological quality of running freshwater based on Hellawell (1978) (in Spanish). Limnética 1988, 4, 51-56.

31. Alba-Tercedor, J.; Jáimez-Cuéllar, P.; Álvarez, M.; Avilés, J.; Bonada, N.; Casas, J.; Mellado, A.; Ortega, M.; Pardo, I.; Prat, N.; et al. Characterization of the ecological status of the Iberian Mediterranean rivers using the index IBWP (former BMWP') (in Spanish). Limnetica 2002, 21, $175-185$.

32. Armitage, P.D.; Moss, D.; Wright, J.F.; Furse, M.T. The performance of a new biological water quality score system based on macroinvertebrates over a wide range of unpolluted running-water sites. Water Res. 1983, 17, 333-347.

33. Pardo, I.; García, L.; Delgado, C.; Costas, N.; Abraín, R. Sampling Protocols Riverine Aquatic Biological Communities in the area of the Minho-Sil River Basin and Cantabrian (in Spanish); Convenio entre la Universidad de Vigo y las Confederaciones Hidrográficas del Miño-Sil y Cantábrico; Universidad de Vigo: Vigo, Spain, 2010.

34. Valladolid, M.; Arauzo, M.; Martínez-Bastida, J.J. Ecological Status of the River Oja (Ebro basin, La Rioja, España), through macroinvertebrates indicators (in Spanish). Limnetica 2010, 29, 393-406.

35. Toro, M.; Robles, S.; Tejero, I.; Cristóbal, E.; Velasco, S.; Sáchez, J.R.; Pujante, A. Group 32. Ecological Type 21. Siliceous Cantabric-Atlantic Rivers. Preliminary Ecological Basis for Conservation of Habitat Types of Community Interest in Spain (in Spanish); Ministerio de Medio Ambiente y Medio Rural y Marino: Madrid, Spain, 2009.

36. Munné, A.; Prat, N.; Solà, C.; Bonada, N.; Rieradevall, M. A simple field method for assessing the ecological quality of riparian habitat in rivers and streams: QBR index. Aquat. Conserv. Mar. Freshw. Ecosyst. 2003, 13, 147-163.

37. Ysi 556 Multi Probe System Operations Manual; YSI Environmental: Yellow Springs, OH, USA, 2009. Available online: http://www.ysi.com/media/pdfs/ (accessed on 16 February 2012). 
38. Alba-Tercedor, J.; Pardo, I.; Prat, N.; Pujante, A. Methodology for Establishing the Ecological Status under the Water Framework Directive. Sampling and Analysis Protocol for Benthic Invertebrates (in Spanish); Ministerio de Medio Ambiente: Madrid, Spain, 2005.

39. Sansoni, G. Atlas for the Identification of Macroinvertebrates from the Italian Watercourses (in Spanish); Provincia Autonoma di Trento, Agenzia Provinciale per la Protezione dell'Ambiente: Trento, Italy, 1998.

40. Estaciones Redes Antiguas; Xunta de Galicia Web site. Available online: http://augasdegalicia. xunta.es/es/Estacions_continentais.htm (accessed on 24 July 2012).

41. Santos, J.M.; Ferreira, M.T.; Pinheiro, A.N.; Bochechas, J.H. Effects of small hydropower plants on fish assemblages in medium-sized streams in central and northern Portugal. Aquat. Conserv. Mar. Freshw. Ecosyst. 2006, 16, 373-388.

42. Costas, N.; Alvarez Jiménez, M.; Pardo Gamundí, I. Characterization of an atlantic salmon "Salmo salar" Stream at the southern limit of its eastern atlantic distribution. J. Fish Biol. 2009, 75, 2552-2570.

43. Peterson, M.J.; Cada, G.F.; Sale, M.J.; Eddlemon, G.K. Regulatory Approaches for Addressing Dissolved Oxygen Concerns at Hydropower Facilities; U.S. Department of Energy: Washington, DC, USA, 2003.

44. Sale, M.J.; Cada, G.F.; Chang, L.H.; Christensen, S.W.; Railsback, S.F.; Francfort, J.E.; Rinehart, B.N.; Sommers, G.L. Environmental Mitigation at Hydroelectric Projects. Volume 1. Current Practices for Instream Flow Needs, Dissolved Oxygen, and Fish Passage; U.S. Department of Energy: Washington, DC, USA, 1991.

45. Copeman, V.A. The impact of micro-hydropower on the aquatic environment. J. Chart. Inst. Water Environ. Manag. 1997, 11, 431-436.

46. Almodovar, A.; Nicola, G.G. Effects of a small hydropower station upon brown trout Salmo trutta L. in the river Hoz Seca (Tagus Basin, Spain) one year after regulation. Regul. Rivers Res. Manag. 1999, 15, 477-484.

47. Boubee, J.A.T.; Williams, E.K. Downstream passage of silver eels at a small hydroelectric facility. Fish. Manag. Ecol. 2006, 13, 165-176.

48. Travade, F.; Larinier, M.; Subra, S.; Gomes, P.; de Oliveira, E. Behaviour and passage of european silver eels (Anguilla anguilla) at a small hydropower plant during their downstream migration. Knowl. Manag. Aquat. Ecosyst. 2010, 398, 1-19.

49. Capel, F.M.; Rodríguez, F.H.; de Jalón Lastra, D.G.; de los Terreros, M.S. Assessing impacts of a hydropower plant: Ebro river, Spain. Hung. J. Ind. Chem. Veszpr. 2000, 2, 1-6.

50. Durif, C.; Elie, P.; Gosset, C.; Rives, J.; Travade, F.; Dixon, D.A. Behavioral study of downstream migrating eels by radio-telemetry at a small hydroelectric power plant. In Biology, Management, and Protection of Catadromous; Dixon, D.A., Ed.; American fisheries Society: Bethesda, MD, USA, 2003; Symposium 33, pp. 343-356.

(C) 2012 by the authors; licensee MDPI, Basel, Switzerland. This article is an open access article distributed under the terms and conditions of the Creative Commons Attribution license (http://creativecommons.org/licenses/by/3.0/). 